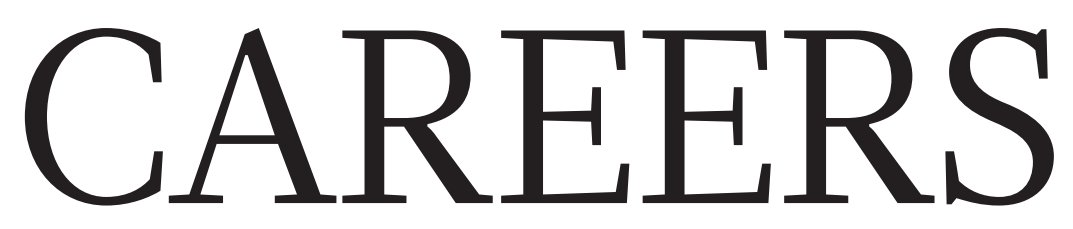

RESEARCH NASA launches programme to study effects of spaceflight p.271
FUNDING MacArthur 'genius grant' to rise to US $\$ 625,000$ this year $\mathbf{p . 2 7 1}$
NATUREJOBS For the latest career

listings and advice www.naturejobs.com

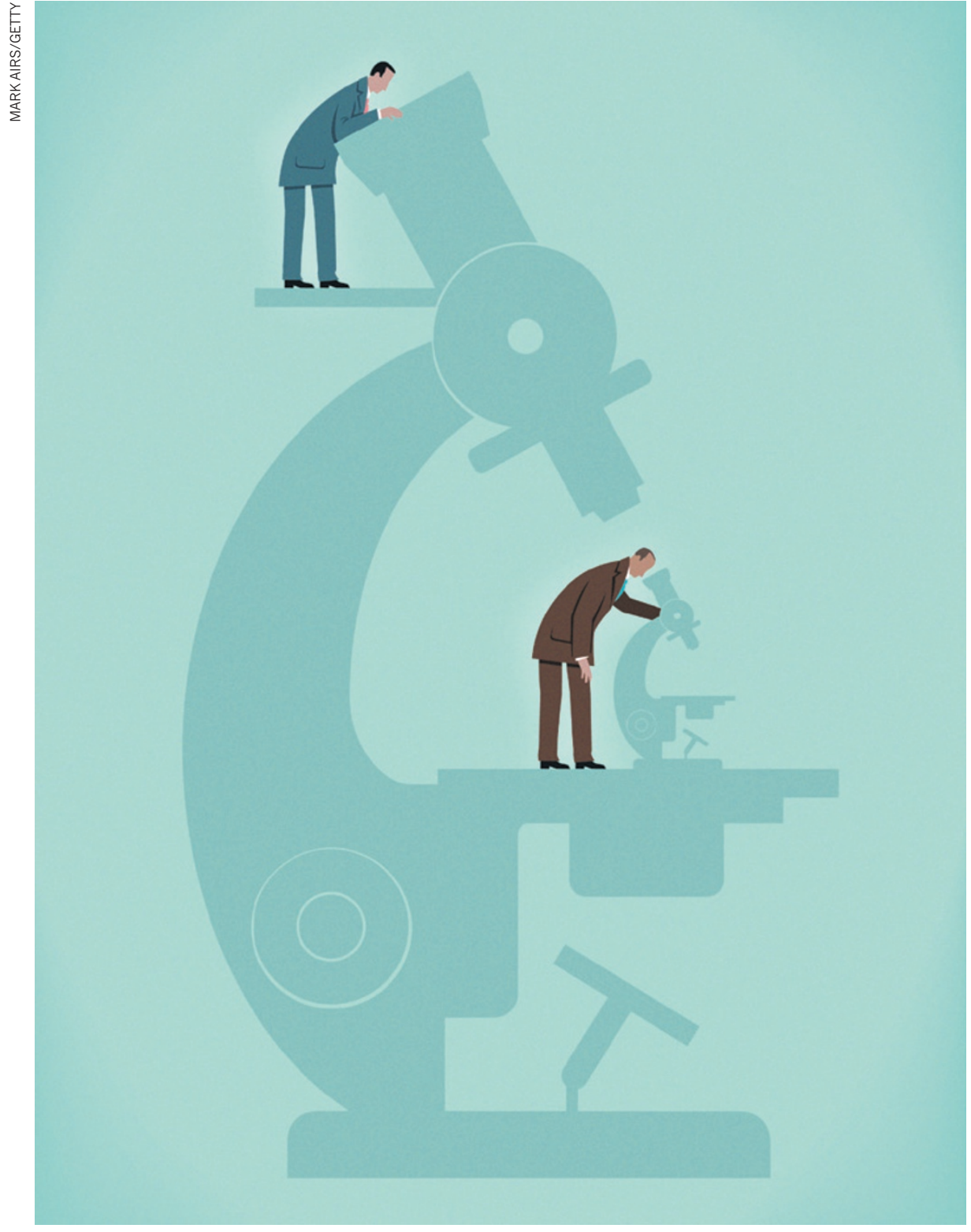

ADMINISTRATION

\section{A watchful eye on grant funding}

Researchers disillusioned with the lab and eager to engage their soft skills can find promise in scientific administration.
BY PAUL SMAGLIK

$\mathrm{M}$ ost scientists worry about how to secure grants. But a select few make a career out of managing those grants to ensure that the money is well spent. This is the job of the scientific administrator.

Broadly speaking, scientific administration involves the awarding, spending and tracking of funding at the grant, programme or policy level. Grant-level administrators assign or manage funds given to individual investigators. Programme administrators look after the needs of multi-investigator or multi-institution projects. And policy administrators oversee funding for entire departments, institutions or even university systems.

Jobs at all levels exist at universities, federal agencies and foundations, and scientific administrators often flip between these worlds at different stages of their careers - perhaps awarding grants at institutions such as the US National Institutes of Health (NIH) or UK biomedical charity the Wellcome Trust at one time, and managing funds at universities at another.

Scientific administrators have a crucial role in the research process, says Ginny Cox Delaney, an organizational consultant in the Oakland Office of the President of the University of California system, which administers ten research universities and five medical centres. "For me, science administration means the value-added role of advancing an organization's research goal, besides doing the actual science," she says.

\section{HUMBLE BEGINNINGS}

Almost no one sets out to be a scientific administrator. Instead, they realize at some point that they would rather support the scientific process away from the bench than at it.

When Elizabeth Prescott started her PhD, she had trouble visualizing where she would be in five years. After graduating, she deliberately chose a postdoc in the lab of a young investigator, at Yale University in New Haven, Connecticut. "I got a first-hand view of what it looked like to be a junior faculty member," says Prescott, noting the long hours the job entailed. "I don't think I love this enough," she thought.

She was considering leaving her fellowship and searching for a job in industry when the director of the postdoctoral-affairs office at Yale told her about an upcoming position. The university was establishing numerous core facilities in fields including DNA sequencing and high-performance computing, and the 
provost's office needed someone to act as a liaison. Apart from a requirement to monitor how effectively the facilities served the needs of the university's scientists, the position was not well defined. So when Prescott got the job, she had a bit of a baptism of fire. "I learned about non-profit accounting; I learned about grant compliance," she says. She also learned to evaluate investigators' needs, and then sort them into different priorities.

In doing so, she became a link between the investigator, the granting agency and other parts of the university. These days, Prescott works as a foundation relations adviser at the Fred Hutchinson Cancer Research Center in Seattle, Washington, where she also acts as a liaison - this time between the centre and the companies and foundations that want to donate to it. Having scientific knowledge gives her credentials with all sides, she says. "It helps to have an understanding, to know what it is like to work in the lab. You don't want to be perceived as a bean counter or a barrier."

'Liaison' is one of many roles of scientific administrators. 'Head of logistics' is another. As a scientific review officer for the NIH in Bethesda, Maryland, Shiv Prasad recruits qualified scientists three times a year to review grant applications. To say that organizational skills are essential in his work would be an understatement, he notes. "When you have 20 or more scientists coming to a study section from around the world, you want to make sure things run like clockwork. That means getting them their applications to review on time, giving them enough notice to make travel plans and making sure rooms are booked."

It takes a certain kind of person to excel in administration - someone who enjoys repeatedly arranging and following up on meetings, and who understands how something as mundane as the wording on a form can affect the application experience, says Jonathan Best, grant operations manager at the Wellcome Trust in London. "I enjoy taking a process and making it work as efficiently as it can," he says. "It takes me to a whole new level of geekdom and challenges me in a totally different way to my previous scientific positions." Best provides help at every step, from application, making sure that the applicant has filed the correct information, to evaluation - seeing that members of the review committee get the applications in time. Currently his office is updating forms and revising deadlines to make the process less onerous for the applicant.

Administering grants also involves monitoring their success and implementation activities that require attention to detail and a willingness to police recipients. After a grant has been awarded, Best helps to monitor how effective it was in advancing the investigator's field. He examines metrics such as publications and citations, as well as less tangible outcomes, including whether recipients have led effectively in their fields rather than following trends.
An ability to deal with deadlines is essential, says Diane McFadden, associate director of the Northeast Biodefense Center at Columbia University in New York - an NIH centre of excellence that involves 28 investigators and 3 postdocs at 12 institutions. With so many different components to manage, deadlines "are constantly hitting you", she says. And attention to detail is paramount: if someone does not fill out a form correctly and McFadden misses the error, funds or equipment could be delayed, slowing down projects.

All these things can be learned on the job, as can an understanding of how the funding and follow-up processes work. What cannot be taught, says Prasad, is a passion for science. Keeping up with the latest advances, helping to shepherd promising ideas through funding and seeing the research turn into successful publications and applications are the most satisfying parts of the job, he says.

\section{ADVANCED ADMINISTRATION}

As administrators gain seniority, they tend to take on broader responsibilities. High-level scientific administrators need to be able to see the big picture, says Carl Rhodes, a senior scientific officer at the Howard Hughes Medical Institute (HHMI) in Chevy Chase, Maryland. He helps the institution to select and review new investigators, who are funded by the HHMI but based at universities. Until recently,

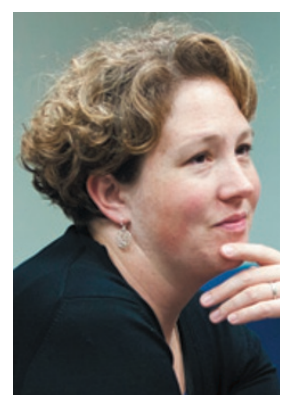

"Science administration means the value-added role of advancing an organization's research goal." Ginny Cox Delaney he also helped to plan and run seven scientific meetings a year. "You need to decide what the agenda is and if it makes sense," he says. "You need to decide how to advertise it, what is the most logical progression for the programme."

Administrators often learn to deal with increasing complexity as they move from monitoring and giving grants to single investigators, to focusing on whole programmes, departments or agencies.

Rhodes started his teaching and administration career at Stanford University in California, where he focused on "things other faculty didn't want to do", he says, such as coordinating teaching assistants, refining the curriculum and dealing with the occasional disciplinary problem. He viewed himself as a service provider. "I made myself useful," he says.

In that role, Rhodes developed key skills and insights that would serve him well in a later job as a grants officer at the NIH, where he managed a review panel that evaluated 
joint PhD-medical doctorate programmes. It was also useful later on: sifting through 1,000 graduate-school applications at a time at Stanford was at least as difficult as triaging hundreds of new-investigator applications at the HHMI, he says. He now oversees scientific advisory panels that evaluate the strengths and weaknesses of each investigator's application and the contributions that they would make to their fields. The review officer combines the panel's comments into a single document - and all the documents go through Rhodes for final approval.

The ability to understand, create and evaluate budgets is essential to scientific administrators - especially as they move up the career ladder. McFadden has become adept at budgeting to make sure that her investigators' needs are met. "I've learned a tremendous amount about building a budget and how to do that with fairness," she says. Some projects deserve extra attention - and providing that, without belittling or alienating other projects in the consortium, can be a delicate process.

Having concrete goals - while keeping in mind a broader picture - is another hallmark of success in upper policy-level administration, says Sue Rosser, provost and vice-president for academic affairs at San Francisco State University in California. "The higher up you get in administration, the more emphasis there is on having a goal and getting things done and on time," she adds. Rosser works to make sure that the myriad meetings that populate her days are not empty exercises, but produce something tangible. "I like to have agendas, outcomes, follow-ups, results," she says. For example, last year her institution decided not to renew funding for a multiyear, multimillion-dollar project that did not fit the university's mission. More than a year before the programme was due to end, Rosser and her team began to have meetings about the closure, with detailed timelines to complete the programme's activities and ensure a smooth transition to an interim grantee. Rosser, like Rhodes, has a service mindset - but she is not so closely connected to the people she helps.

"I am trying to help the faculty under me succeed," she says. "And I am not even directly doing that, I am helping deans help chairs help faculty."

\section{A WAY IN}

Most people who move from a research career to scientific administration do so when they realize that lab work does not meet their life and career goals. There is no obvious, wellworn career path that reliably culminates in an administrative post, but there are ways to get a foothold - and to find out whether it is the right route. When Cox Delaney recognized that she did not have "the golden hands" needed to succeed in the lab, she got a public-policy fellowship from the American
Association for the Advancement of Science in Washington DC. That had her working on science-policy cooperation between the United States and western Europe, which helped her to develop her interpersonal communication skills. A subsequent job at the Alfred P. Sloan Foundation, a non-profit granting organization based in New York, taught her about scientific funding.

Cox Delaney says that graduate students and postdocs who think they might be interested in administration can gather experience by running symposia, planning

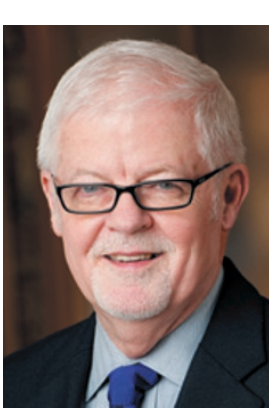
talks, dealing with caterers or booking speakers and venues for conferences. "There are a lot of opportunities to step up into leadership roles," she says. "That will give you a sense of whether you like the organizing piece."

"Youneed to decide what is the most logical progression for the programme." Carl Rhodes

Even pulling authors together for a paper or coordinating a simple event such as a journal club can help, if the organizers can observe the people they are working with and find out what motivates them, or can build new skills, says Cox Delaney. She is currently working with all the University of California campuses to find ways to share and save on administrative costs, so that they can pass the savings on to research and education.

Advancing in administration often means nurturing a skill set that goes well beyond research. Cox Delaney puts people who go into scientific administration into two categories: people with a strong understanding of science and good interpersonal skills; and people adept at accounting and funding. Administrators who have both sets of traits are relatively rare - and they are the ones who tend to rise to the highest levels, she says.

Many universities - especially publicly funded, research-based ones - recruit their leading managers from a pool of scientists, who tend to be detail-oriented and adept at handling complexity, and researchers with a particular appetite and aptitude for managing budgets and people will have multiple career options in administration. The path to broader responsibilities, or even a university presidency, could begin with shepherding a single grant.

Paul Smaglik is a freelance writer based in Milwaukee, Wisconsin.

\section{RESEARCH}

\section{Biology in space}

NASA is launching an open-ended research programme to investigate how human and other tissue reacts to time spent in space. The geneLAB project will begin seeking grant applications by autumn 2014, says D. Marshall Porterfield, director of space life and physical sciences research at NASA in Washington DC. It will award 'innovation exploration' grants of US\$100,000 for one year; full grants will be for up to 5 years and worth a maximum of $\$ 500,000$. The agency wants to send organisms including fruitflies and roundworms to the International Space Station to learn how spaceflight affects living tissue at the biomolecular and genetic level. Future grant recipients would also study bone loss and examine tissue from crew members to look for changes to their DNA that occurred while in space and after returning to Earth.

\section{GENDER}

\section{Mothers' careers stalled}

Attitudes about motherhood can impede women's career aspirations, even at companies that purport to have family-friendly policies, a study suggests (C. Herman et al. Gender Work Organ. 20, 467-478; 2013). Women working in science, engineering and technology at multinational corporations in the Netherlands, France and Italy adopted potentially career-damaging tactics including, for example, avoiding big projects and disguising the need to leave early or come in late because of childcare obligations, the study found. Firms must take stock of how attitudes stymie women who are looking to advance, says study co-author Anne Laure Humbert, a gender researcher at the European Institute for Gender Equality in Vilnius.

\section{FUNDING}

\section{Genius grant grows}

Awards for the MacArthur Fellows Program, known as genius grants, will this year rise from US $\$ 500,000$ to $\$ 625,000$. The John D. and Catherine T. MacArthur Foundation in Chicago, Illinois, makes unrestricted 5-year grants to recipients chosen for their creativity, innovation and potential to shape the future. Spokesman Andrew Solomon says that the increase is partly a response to inflation and is the programme's fourth rise since it began in 1981. The 2013 fellows will be announced on 25 September. 